\title{
Separation of ultrafine particles from class $F$ fly ashes
}

\author{
Ilker Acar ${ }^{1, a}$, Thomas L. Robl ${ }^{2}$, and M. Umit Atalay ${ }^{3}$ \\ ${ }^{1}$ Ataturk University, Faculty of Earth Sciences, Department of Petroleum and Natural Gas Engineering, Erzurum, \\ Turkey \\ ${ }^{2}$ University of Kentucky, Center for Applied Energy Research, Lexington, USA \\ ${ }^{3}$ Middle East Technical University, Department of Mining Engineering, Ankara, Turkey
}

\begin{abstract}
In this study, ultrafine particles were recovered from Çatalağzı (CFA) and Sugözü (SFA) thermal power plant fly ashes using a specific hydraulic classification technology. Since fly ashes have a high tendency to be flocculated in water, settling experiments were first designed to determine the more effective dispersant and the optimum dosage. Two different types of the superplasticizers (SP) polymers based on sulphonate (NSF, Disal) and carboxylate (Glenium 7500) were used as the dispersing agents in these settling experiments. Hydraulic classification experiments were then conducted to separate ultrafine fractions from the fly ash samples on the basis of the settling experiments. According to the settling experiments, better results were achieved with the use of Disal for both CFA and SFA. The classification experiments showed that the overflow products with average particle sizes of $5.2 \mu \mathrm{m}$ for CFA and $4.4 \mu \mathrm{m}$ for SFA were separated from the respective as-received samples with acceptable yields and high enough recoveries of $-5 \mu \mathrm{m}$ (ultrafine) particles. Overall results pointed out that the hydraulic classification technology used provided promising results in the ultrafine particle separations from the fly ash samples.
\end{abstract}

\section{Introduction}

Fly ash can be defined as the main waste residue resulted from the combustion of either ground or powdered coal and occurred as a fine powder of mainly spherical and glassy particles [1-3]. Coal properties, combustion conditions and storage methods determine the mineralogy, chemistry and physical properties of fly ash. Therefore, fly ash derived from burning of different types of coal (e.g., anthracite, bituminous and lignite coal) has different chemical compositions and physical properties [4-5].

Fly ash has a wide-range of particle size varying from sub-micron to $500 \mu \mathrm{m}$. Specific gravity of fly ash varies in the range $2.1-2.6$, while bulk density ranges from 1 to $1.8 \mathrm{~g} / \mathrm{cm}^{3}$ [5]. Chemically, fly ash includes major $(>1 \%)$, minor $(1-0.1 \%)$ and trace $(<0.1 \%)$ elements. Since it is a combusted material, the major and minor elements are present as oxides. In order of decreasing amounts, these elements are commonly $\mathrm{O}, \mathrm{Si}, \mathrm{Al}, \mathrm{Ca}, \mathrm{Fe}, \mathrm{C}, \mathrm{K}, \mathrm{Mg}, \mathrm{H}, \mathrm{Na}, \mathrm{Ti}, \mathrm{N}, \mathrm{P}$, and $\mathrm{Ba}$. The other elements are mostly present in trace amounts in fly ash [6].

a Corresponding author: ilker.acar@atauni.edu.tr 
Fly ash utilization has increased in recent years due to its various environmental, economic and technical benefits. Firstly, less environmental pollution occurs in fly ash disposal area. Secondly, lower disposal costs and less area requirement for disposal are also provided with the use of this combustion waste. Further environmental and economic benefits take place when fly ash is used as a partial replacement material for some important natural resources. In addition, fly ash can be used as an essential additive in some sector to improve the properties of final products, such as special pozzolanic additive in cement and concrete industries [7].

According to the American Coal Ash Association (ACAA) and European Coal Combustion Products Association (ECOBA), utilization of total produced fly ash in 2013 in US was 43.7\%, while in 2010 this utilization was $43.0 \%$ in Europe (EU-15 Countries). The majority of these utilizations were in the cement and concrete industries for both US and Europe. Thus, for the remaining material, disposal practices are used involving ash ponds, lagoons and landfills. However, all of them can be considered as environmentally undesirable use of land resources [8]. In order to increase the utilization potentials, heterogeneous as-received fly ashes should be subjected to a treatment for removal of contaminants and separation of particles into size ranges providing fly ash utilization in a wide-range of added value applications. One of the highest-value fractions in coal fly ashes is ultrafine particles which have a great potential as a suitable filler material for plastic polymers, concrete and cement [9-10].

Today, hydrocyclone and hydraulic classifiers are the most widely used classifiers in mineral processing. For separation of fine particles, hydrocyclones are commonly used in most applications down to $75 \mu \mathrm{m}$ and smaller size cyclones can be used to separate fine particles down to a few microns. However, in addition to the problem of plugging due to small openings of the cyclone, the capacity is also reduced under this condition. On the other hand, conventional hydraulic classifiers are usually designed to obtain clean coarse fractions without slimes. The hydraulic classifiers have a major disadvantage known as "blanket settling" which can be defined as the hindering of smaller particles' upward movements due to coarser particles. As expected, the hydraulic classifiers generally provide very low yield and recovery for separation of very fine particles [11].

Hydraulic classification is mainly based on the size and density of a material. In hydraulic classification systems, fly ash generally tends to flocculate and these flocs are considerably stable even for high $\mathrm{pH}$ values. In literature, some known chemicals such as sodium silicate and potassium hydroxide have been used to disperse the flocs. However, these attempts have not given satisfying results for classification of fly ash. Some good results have been obtained with potassium metaphosphate and pyrophosphate [9]. On the other hand, these results have been erratic and highly substrate dependent. Therefore, it is required to find another dispersants producing high yield.

Some chemicals known as "superplasticizers" (SP), which are a group of organic water soluble polymers with long molecules of high molecular mass, are largely used in the cement and concrete industry because of their contributions to dispersion and water reduction properties. According to some projects, these chemicals can also be used as effective dispersing agents for separation of ultrafine particles $[9,11]$.

In this study, it was aimed to separate the ultrafine fractions $(-5 \mu \mathrm{m})$ from the as-received Çatalağzı (CFA) and Sugözü (SFA) fly ashes with high enough recoveries and acceptable yields using a specific hydraulic classification technology. For this purpose, settling experiments were first designed to determine more effective dispersant and the optimum dosage. The hydraulic classification experiments were then conducted to separate ultrafine particles from the as-received class $\mathrm{F}$ fly ashes on the basis of the settling experiments. 


\section{Experimental}

\subsection{Materials}

The coal fly ash samples used in this study were obtained from Çatalağzı and Sugözü thermal power plants in Turkey. Both of the fly ashes were resulted from burning of bituminous coals. A Spectro IQ X-ray fluorescence (XRF) spectrometer was used to determine major chemical constituents of the fly ashes. Loss-on-ignition (LOI) tests were performed in accordance with ASTM C 311. A Malvern Hydro 2000S particle size analyzer was used to determine particle size distributions of the samples. Porosity measurements were conducted using a mercury porosimeter. Density measurements were carried out using a helium pycnometer. Specific surface area values were determined with BET nitrogen adsorption method. Table 1 shows the major chemical constituents and basic physical properties of the as-received fly ash samples.

Table 1. Major chemical constituents and basic physical properties of the samples.

\begin{tabular}{|l|c|c|}
\hline Chemical composition (\%) & Çatalăgz (CFA) & Sugözü (SFA) \\
\hline $\mathrm{SiO}_{2}$ & 57.09 & 63.35 \\
\hline $\mathrm{Al}_{2} \mathrm{O}_{3}$ & 27.46 & 22.01 \\
\hline $\mathrm{Fe}_{2} \mathrm{O}_{3}$ & 6.56 & 7.90 \\
\hline $\mathrm{CaO}$ & 1.97 & 1.45 \\
\hline $\mathrm{MgO}$ & 2.38 & 2.31 \\
\hline $\mathrm{Na}_{2} \mathrm{O}$ & 0.31 & 0.79 \\
\hline $\mathrm{K}_{2} \mathrm{O}$ & 3.89 & 1.95 \\
\hline $\mathrm{P}_{2} \mathrm{O}_{5}$ & 0.11 & 0.16 \\
\hline $\mathrm{TiO}_{2}$ & 1.13 & 0.91 \\
\hline $\mathrm{SO}_{3}$ & $<0.01$ & $<0.01$ \\
\hline $\mathrm{LOI}(\%)$ & 1.68 & 2.15 \\
\hline Physical properties & \multicolumn{2}{|l|}{} \\
\hline Density $\left(\mathrm{g} / \mathrm{cm}^{3}\right)$ & 2.08 & 2.36 \\
\hline Average particle size $(\mu \mathrm{m})$ & 39.29 & 21.42 \\
\hline Total porosity $(\%)$ & 19.99 & 6.97 \\
\hline Surface area $\left(m^{2} / g\right)$ & 0.8284 & 1.1715 \\
\hline
\end{tabular}

According to Table 1, the major chemical constituents of the fly ash samples were $\mathrm{SiO}_{2}, \mathrm{Al}_{2} \mathrm{O}_{3}$ and $\mathrm{Fe}_{2} \mathrm{O}_{3}$. This result indicated that both of the fly ashes met the chemical requirements to be a class $\mathrm{F}$ fly ash consistent with ASTM C 618 due to their high amounts of silica, aluminum oxide and ferric oxide and low amounts of sulfur trioxide and LOI values. Since the fly ash samples were bituminous coal combustion residues, both of them had low lime contents. The differences in average particle sizes between the fly ashes can also clearly be seen from Table 1 . Çatalağzı fly ash has an average particle size of $39.29 \mu \mathrm{m}$, nearly two times greater in comparison to Sugözü fly ash. Table 1 also shows that Sugözü fly ash had the higher density and surface area and lower porosity values than Çatalağzı fly ash.

Mineralogical compositions of the samples were determined using X-ray powder diffraction (XRD). The XRD results indicated that quartz, mullite and hematite were the main crystalline phases for both samples. Scanning electron microscopy (SEM) was used to examine microstructural properties of the fly ashes. According to the SEM observations, the fly ash samples mainly contained small and glass like particles with spherical shape and also larger irregularly shaped particles. 


\subsection{Methods}

In this study, ultrafine fractions of Çatalağzı (CFA) and Sugözü (SFA) thermal power plant fly ashes were separated using a specific hydraulic classification technology. In order to accomplish this, fly ash particles had to be dispersed prior to classification. Therefore, settling experiments were first conducted to determine more effective dispersant and its optimum dosage. Based on these settling experiments, the ultrafine particles were recovered from the as-received fly ashes using a specific hydraulic classifier.

\subsubsection{Settling experiments}

Two different types of superplasticizers (SP) polymers based on sulphonate (NSF, Disal) and carboxylate (Glenium 7500) were used as the dispersing agents in the settling experiments. Unlike NSF dispersant (Disal), Glenium 7500, which is a high range water reducing admixture, is based on the next generation of polycarboxylate technology. Dispersant dosages of 0.5, 1.0, 1.5, 2.0, 2.5 and 3.0 $\mathrm{mg} / \mathrm{g}$ of fly ash were tested in these experiments. Also, control experiments were done without dispersants to observe the differences. In these experiments, pulps with $1.5 \%$ solid content were prepared in a $250 \mathrm{ml}$ graduated cylinder. After the required amount of dispersant added to the fly ash pulp, the graduated cylinder was well mixed for a minute. The pulp was taken down to $100 \mathrm{ml}$ level using a vacuum pump after 5 minutes of settling time. After filtration and drying, the sample was weighed. Weight percentages of solid in the floating products were used as the measure of dispersant efficiency.

\subsubsection{Hydraulic classification}

The hydraulic classification process developed at the CAER (University of Kentucky, Center for Applied Energy Research) laboratory is based on a method for cross-flow of particles in slurry for selective separation of fine particles. Particle separation in this process was accomplished with the use of particle velocity differences in water (influenced by density, size and shape of particles). The particular system was a modified version of lamella hydraulic classifier (LHC), in which interior dividers were placed for effective removing of coarse particles from the system by increasing the settling area. The bottom of the classifier was separated into four underflow discharge areas for selective removal of particles with sequentially decreasing size. Ultrafine particles were obtained from overflow discharge area [11-12]. The lamella hydraulic classifier (LHC) used in this study is schematically illustrated by Figure 1 .

In this hydraulic classification process, the important process parameters were the feed pulp density, feed rate, underflow discharge rates, type and dosage of dispersant and divider spacing. Prior to each experiment, slurry feed rates and the dispersant dosage were carefully adjusted to the desired values. Then, the classifier was filled with water up to the level of discharge pipe, and discharge rates of underflows were adjusted to remove the coarse particles from the system. After that, the classification process started. The slurry and mass flow rates of feed, overflow and underflow products were checked two times by taking the samples from each for a definite period of time during the process. After the experiment, percentage of solids and loss-on-ignition (LOI) values of feed, overflow and underflow were measured. Particle sizes of the all fractions were measured using a Malvern Hydro 2000S particle size analyzer. Figure 2 shows the lamella hydraulic classifier (LHC) during the experiment. 


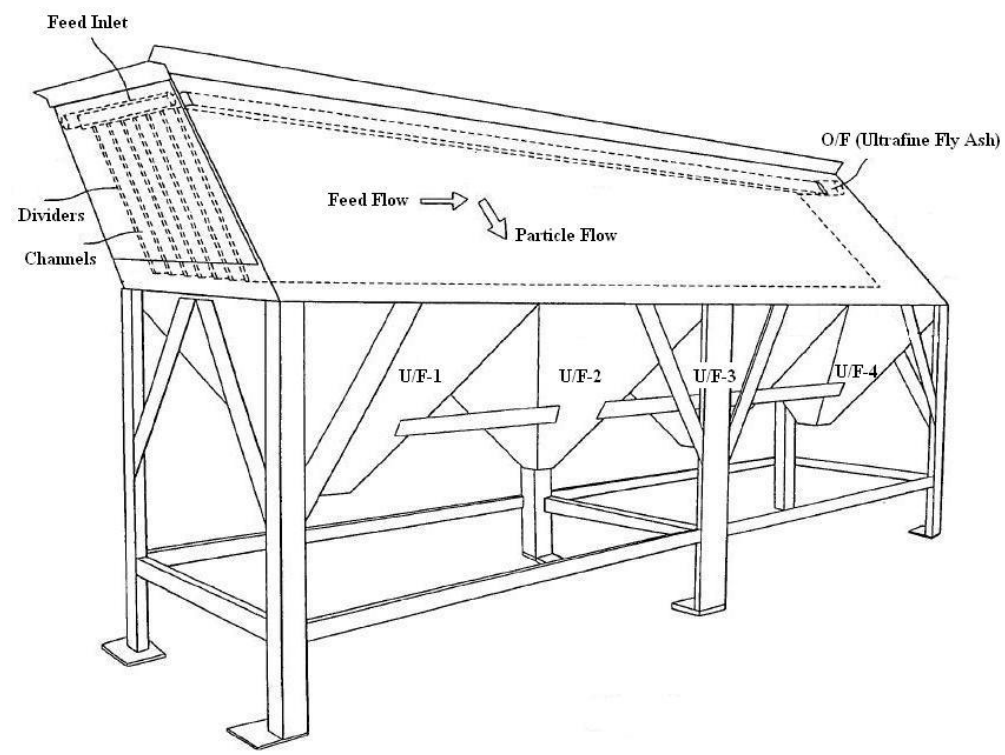

Figure 1. Schematic representation of the lamella hydraulic classifier (LHC).

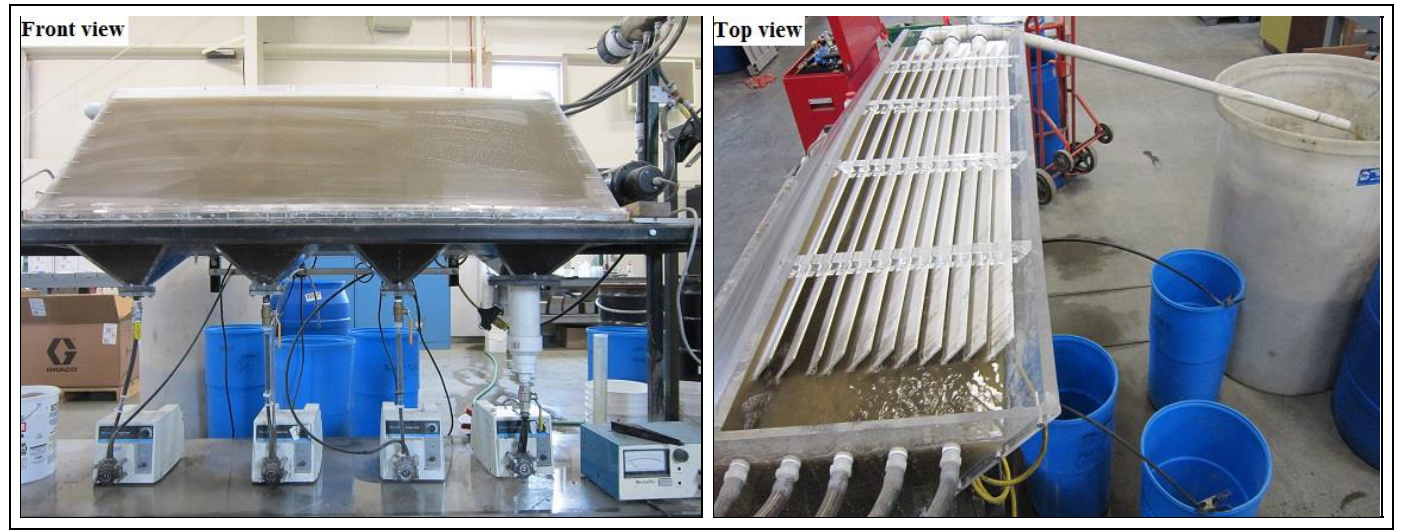

Figure 2. The lamella hydraulic classifier (LHC) during the experiment.

In this process, the product grade was defined as the mean particle size of the overflow on volumetric basis. In addition to overflow mean size, yield and recovery were also calculated as measures of processing efficiency according to equations:

$$
\begin{gathered}
\text { Product yield }=\frac{\text { Mass of product solids }}{\text { Mass of feed solids }} \\
\text { Product recovery }=\frac{\text { Mass of product solids finer than } 5 \mu \mathrm{m}}{\text { Mass of feed solids finer than } 5 \mu \mathrm{m}} .
\end{gathered}
$$

Some codes were given to the as-received fly ashes (FA) and their ultrafine fractions (UFA) through the experiments. These codes were CFA (ÇatalağZı FA), CUFA (ÇatalağZı UFA), SFA (Sugözü FA) and SUFA (Sugözü UFA). 


\section{Results and discussion}

\subsection{The results of settling experiments}

Two different types of superplasticizer polymers based on sulphonate (NSF, Disal) and carboxylate (Glenium 7500) were used in these experiments to determine their dispersive effects on CFA and SFA samples. Figures 3 and 4 illustrate the results of settling experiments for CFA and SFA, respectively.

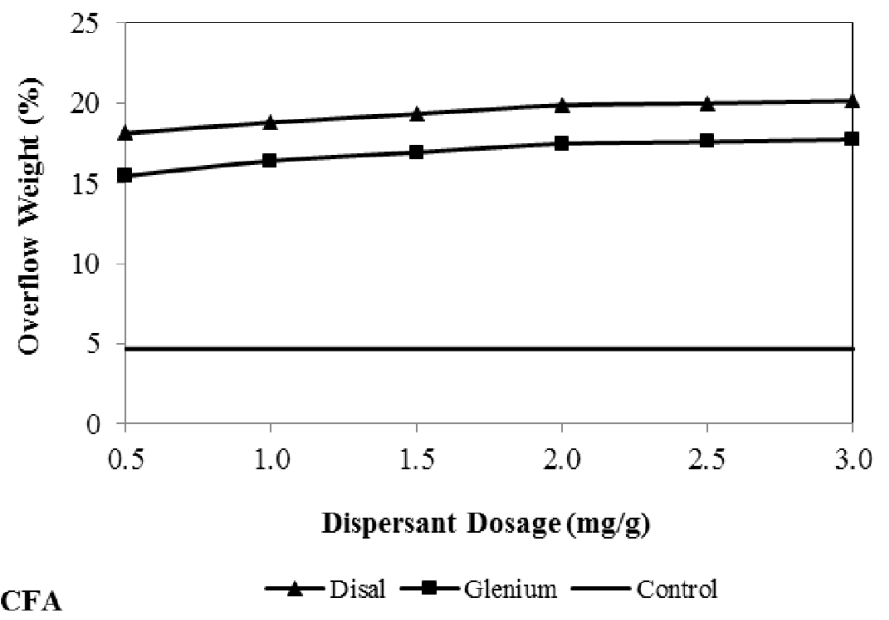

Figure 3. The results of settling experiments for Çatalağzı fly ash (CFA).

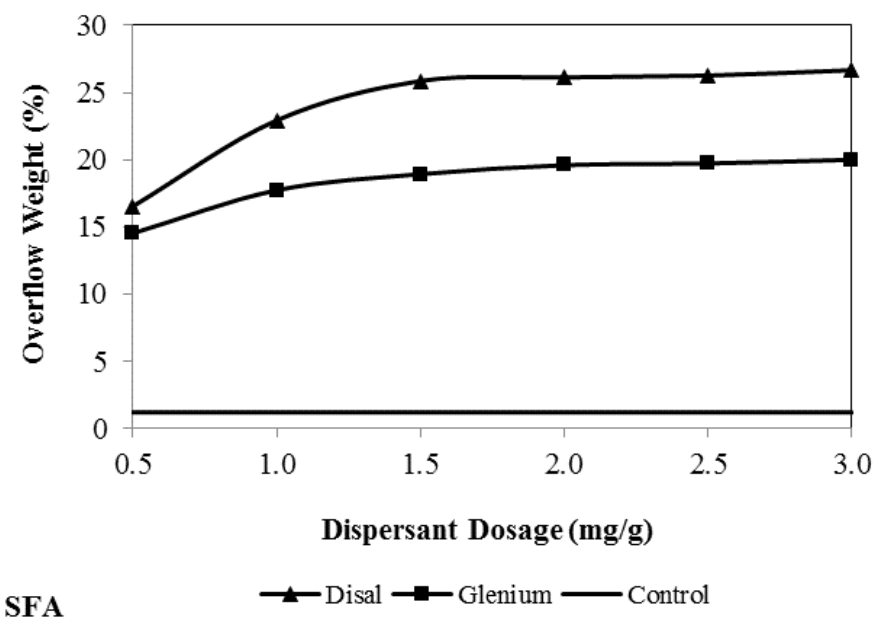

Figure 4. The results of settling experiments for Sugözü fly ash (SFA).

Figures 3 and 4 show that overflow weight percentages of the fly ash samples increased with increasing dispersant dosage. However, for both dispersants, very small increases in the overflow weight percentages were observed beyond the dispersant dosages of $2.0 \mathrm{mg} / \mathrm{g}$ for CFA and $1.5 \mathrm{mg} / \mathrm{g}$ for SFA. Although both dispersants showed the same patterns, better results were achieved with the use of Disal for both CFA and SFA. Figures 3 and 4 also indicate that very low overflow weight percentages were obtained without the addition of dispersants. 


\subsection{Hydraulic classification}

\subsection{1 Çatalağzı fly ash}

The classification conditions and obtained results for Çatalağzı fly ash are shown in Tables 2 and 3, respectively. According to Table 3, from CFA with average particle size $\left(d_{50}\right)$ of $39.29 \mu \mathrm{m}$, the ultrafine fraction (CUFA) with average particle size of $5.25 \mu \mathrm{m}$ was separated with $10.75 \%$ yield and $53.28 \%$ recovery of $-5 \mu \mathrm{m}$ particles in the overflow $(\mathrm{O} / \mathrm{F})$ product.

Table 2. Classification conditions for CFA.

\begin{tabular}{|l|l|}
\hline Operating conditions & \\
\hline Feed pulp density & $1.5 \%$ solids by wt. $(0.015 \mathrm{~kg} / \mathrm{l})$ \\
\hline Feed rate & $11 \mathrm{~min}$ \\
\hline \multirow{2}{*}{ Underflow discharge rates } & $\mathrm{U} / \mathrm{F}-1=300 \mathrm{cc} / \mathrm{min}, \mathrm{U} / \mathrm{F}-2=200 \mathrm{cc} / \mathrm{min}$ \\
& $\mathrm{U} / \mathrm{F}-3=200 \mathrm{cc} / \mathrm{min}, \mathrm{U} / \mathrm{F}-4=200 \mathrm{cc} / \mathrm{min}$ \\
\hline Dispersant & Disal \\
\hline Dispersant dosage & $2.0 \mathrm{mg}$ Disal $/ \mathrm{g}$ of fly ash \\
\hline
\end{tabular}

Table 3. Classification results for CFA.

\begin{tabular}{|l|c|c|c|c|c|}
\hline Products & Weight (\%) & Solid (\%) & $\boldsymbol{d}_{\mathbf{5 0}}(\boldsymbol{\mu} \mathbf{m})$ & Vol. \% of -5 $\boldsymbol{\mu m}$ & $\mathbf{- 5} \boldsymbol{\mu m}$ recovery (\%) \\
\hline U/F-1 & 38.80 & 16.90 & 63.26 & 3.84 & 15.41 \\
\hline U/F-2 & 27.98 & 18.98 & 47.25 & 4.08 & 11.81 \\
\hline U/F-3 & 13.90 & 8.60 & 36.62 & 4.94 & 7.10 \\
\hline U/F-4 & 8.56 & 5.31 & 21.46 & 8.10 & 7.17 \\
\hline O/F (Ultrafine) & 10.75 & 0.16 & 5.25 & 47.91 & 53.28 \\
\hline Total (feed) & $\mathbf{1 0 0 . 0 0}$ & $\mathbf{1 . 4 9}$ & $\mathbf{3 9 . 2 9}$ & $\mathbf{9 . 6 7}$ & \\
\hline
\end{tabular}

\subsubsection{Sugözü fly ash}

Classification conditions and the obtained results for Sugözü fly ash (SFA) are shown in Tables 4 and 5 , respectively. Smaller underflow rates were chosen this time because of the smaller particle size of SFA compared to that of CFA. According to Table 5, the average size of $4.41 \mu \mathrm{m}$ particles was obtained with $17.51 \%$ yield and $63.13 \%$ recovery of $-5 \mu \mathrm{m}$ particles in the overflow product (SUFA). In other words, finer particle size with higher yield and recovery was obtained in this experiment compared to the hydraulic classification test of CFA.

Overall results obtained from the classification tests of Çatalağzı and Sugözü fly ashes indicated that the hydraulic classification technology developed at CAER gave good results for recovery of very fine particles with acceptable yields and high enough recoveries.

Table 4. Classification conditions for SFA.

\begin{tabular}{|l|l|}
\hline Operating conditions & \\
\hline Feed pulp density & $1.5 \%$ solids by wt. $(0.015 \mathrm{~kg} / \mathrm{l})$ \\
\hline Feed rate & $11 \mathrm{~min}$ \\
\hline \multirow{2}{*}{ Underflow discharge rates } & $\mathrm{U} / \mathrm{F}-1=200 \mathrm{cc} / \mathrm{min}, \mathrm{U} / \mathrm{F}-2=150 \mathrm{cc} / \mathrm{min}$ \\
& $\mathrm{U} / \mathrm{F}-3=150 \mathrm{cc} / \mathrm{min}, \mathrm{U} / \mathrm{F}-4=150 \mathrm{cc} / \mathrm{min}$ \\
\hline Dispersant & Disal \\
\hline Dispersant dosage & $1.5 \mathrm{mg}$ Disal $/ \mathrm{g}$ of fly ash \\
\hline
\end{tabular}


Table 5. Classification results for SFA.

\begin{tabular}{|l|c|c|c|c|c|}
\hline Products & Weight (\%) & Solid (\%) & $\boldsymbol{d}_{\mathbf{5 0}}(\boldsymbol{\mu} \mathbf{m})$ & Vol. \%o of $\mathbf{- 5} \boldsymbol{\mu m}$ & $\mathbf{- 5} \boldsymbol{\mu m}$ recovery (\%) \\
\hline U/F-1 & 32.18 & 21.45 & 34.13 & 5.43 & 11.27 \\
\hline U/F-2 & 25.69 & 23.08 & 32.63 & 5.52 & 9.15 \\
\hline U/F-3 & 13.63 & 12.35 & 26.90 & 6.40 & 5.63 \\
\hline U/F-4 & 11.00 & 9.96 & 16.31 & 9.76 & 6.93 \\
\hline O/F (Ultrafine) & 17.51 & 0.23 & 4.41 & 55.90 & 63.13 \\
\hline Total (feed) & 100.00 & 1.46 & 21.42 & 15.50 & \\
\hline
\end{tabular}

\section{Conclusion}

The hydraulic classification technology used to separate ultrafine fractions from the as-received samples was resulted in promising results. The overflow products with average particle sizes of 5.2 $\mu \mathrm{m}$ for CFA and $4.4 \mu \mathrm{m}$ for SFA were separated from the respective as-received samples with average particle sizes of 39 and $21 \mu \mathrm{m}$. The ultrafine fraction of CFA (CUFA) was separated with $10.75 \%$ yield and $53.28 \%$ recovery of $-5 \mu \mathrm{m}$ particles in the overflow product while $17.51 \%$ yield and $63.13 \%$ recovery were obtained for the ultrafine fraction of SFA (SUFA). Finer particle size could be obtained with this hydraulic classification technology. However, in this case, yield and recovery values would decrease. The results obtained from all the experiments conducted within the scope of classification indicate that the hydraulic classification technology developed at CAER gave good results for the recovery of ultrafine particles.

\section{References}

1. S. V. Vassilev, R. Menendez, D. Alvarez, M. Diaz-Somoano, M. R. Martinez-Tarazona, Fuel 82, 1793 (2003).

2. ASTM C 618, Standard specification for coal fly ash and raw or calcined natural pozzolan for use in concrete, ASTM International, West Conshohocken, PA, USA (2012).

3. BS EN 450-1, Fly ash for concrete: Definition, specifications and conformity criteria, BSI, London, UK (2005).

4. I. Acar, M. U. Atalay, Fuel 106, 195 (2013).

5. S. Jala, D. Goyal, Bioresour. Technol. 97, 1136 (2006).

6. V. Vassilev, C. G. Vassileva, Fuel 86, 1490 (2007).

7. M. Ahmaruzzaman, Prog Energy Combust 36, 327 (2010).

8. I. Acar, M. U. Atalay, Fuel 180, 97 (2016).

9. T. L. Robl, J. G. Groppo, Technology and methodology for the production of high quality polymer filler and super-pozzolan from fly ash, United States Patent (Patent No: US 6,533,848 B1) (2003).

10. M. R. Jones, M. J. McCarthy, L. Zheng, T. L. Robl, J. Groppo, in Proceeding of World of Coal Ash (WOCA) Conference (2009).

11. T. L. Robl, J. G. Groppo, Method for hydraulically separating carbon and classifying coal combustion ash, United States Patent (Patent No: US 7,963,398 B2) (2011).

12. M. J. McCarthy, M. R. Jones, L. Zheng, T. L. Robl, J. G. Groppo, Fuel 111, 430 (2013). 